\title{
STATE LEGISLATION FOR RURAL DEVELOPMENT: THE ROLE OF THE UNIVERSITY
}

\author{
Brady J. Deaton and Thomas G. Johnson*
}

\section{Introduction}

The role of state governments in developing and implementing economic policy has taken on greater importance in the U.S. under New Federalism. A recent OECD Conference revealed that similar issues confront most of the Western democracies and, in fact, may indicate the emergence of a new form of governance with profound implications for the distribution of power among levels of governments within each nation (Jequier). ${ }^{1}$ Clearly, both economic and political relationships will be shaped by the resulting patterns of authority that emerge from this process.

The purpose of this paper is twofold. The first is to describe a rural development institution conceived and borne of the efforts of state government agencies and an academic institution. The second purpose is to relate the process involved in this cooperative undertaking. We hope that it will be obvious how much the product of such a cooperative undertaking is influenced by the day to day twists and turns of the process. We will first discuss the background and assumptions upon which this new institution is based. Secondly, the institution's structure and its underlying rationale will be described. Finally, we will address the university's role in the process, as one example of an academic institution's contribution to state policy.

\section{Background and Assumptions}

A close working relationship between research and extension faculty at Virginia Tech and state government was strengthened by Title V of the Rural Development Act of 1972. State government personnel were members of the Title V Advisory Committee and were participants in various workshops and conferences conducted as part of this rural development program. The demise of funding for integrated research-extension work under the auspices of a state-wide advisory committee has not diminished either university-state government cooperation or the emphasis on rural development work in Virginia. Title $\mathrm{V}$ was an important building block in a process that has been carried forward by socio-economic changes and attempts to redefine the roles of federal, state and local governments. The New Federalism has forced all levels of government to take a new look at the potential resources, including leadership, that can be provided by a creative partnership between the public and private sectors.

\section{A Convergence of Efforts}

The need to develop a state rural development policy was recognized by both university and state government officials as early as 1980 . For example, a working group of research-extension faculty at Virginia Tech developed a statement in 1980 which included the following points:

1. Virginia citizens should establish a viable rural development policy for the state in order to: (a) provide guidelines for allocating federal revenue in programs designed to improve rural areas of Virginia, and (b) provide an important set of constructs to steer state and local resources and to provide incentives for private capital investment, job training programs, volunteer activities, and

*The authors are Professor and Assistant Professor, respectively, Department of Agricultural Economics, Virginia Polytechnic Institute and State University, Blacksburg, Virginia. 
other community based activities related to community and economic development.

2. The state rural development policy should be "indicative" and not "prescriptive." That is, it should provide general direction for state and local policy, private business decisions, and for citizens engaged in volunteer activities.

3. A program of integrated research and educational efforts should be undertaken to provide the foundations for a viable rural development policy for Virginia. The educational program would have as a major goal to enable the citizens of Virginia to identify their priority needs in view of information about the resource potential of Virginia and the additional resources that can be brought to bear on the state's problems.

Within the state government, a Rural Affairs Study Commission was created in 1969 and a Joint Subcommittee on Rural Affairs in 1980 emphasized the need for promoting diversity and rural economic development. The Governor established a Rural Development and Capacity Building Council in 1981 which was made up of public and private sector representatives. The Council was chaired by the Secretary of Commerce and Resources - one of four policy-level commissioners who report directly to the Governor.

In March 1981, the Governor's Rural Development and Capacity Building Council established a Rural Venture Committee to make an appraisal of the need to strengthen aspects of the economic and social development of Virginia farmers and rural areas throughout Virginia. Six proposals were studied by different subcommittees. The Rural Development Authority Subcommittee was composed of representatives from the Virginia Department of Agriculture and Consumer Services, Virginia Polytechnic Institute and State University, Virginia State University, Cooperative Extension Service, other State Agencies, Federal Agencies, and the private sector. The Department of Agricultural Economics and the Extension Community Resource Development Division of Virginia Tech were active members of this subcommittee.

The committee met three times during the spring and summer of 1981 and determined that a clearly defined policy for rural development with appropriate strategies for action was definitely needed in Virginia. The Rural Venture Committee placed emphasis on the observation that farm problems go beyond the farm gate and that rural community development must be based on a broad economic approach. The growing dependence of farm families on off-farm income sources was recognized. ${ }^{2}$

On October 7, 1981, in its report to the Governor's Rural Development and Capacity Building Council, the Rural Venture Committee recommended that a public/private partnership be created as a mechanism to concentrate on economic development of rural areas. In response to the Rural Venture Committee's recommendation, a Virginia Rural Development Authority Task Force was established by the Council to study the feasibility of such a mechanism.

\section{Policy Issues}

The Rural Development Authority Task Force delineated a set of general concerns that influenced the form of the Rural Virginia Development Foundation. The general concerns included the following:

1. The free enterprise system depends on state and local government to act as "cooperators" and as "providers" of many essential services and resources.

2. The diverse activities of state and local government and multicounty planning district commissions most effectively serve the needs of the private business sector and the public for essential services when sufficiently coordinated.

3. The level of economic development varies significantly among communities. Some are experiencing rapid population growth and increased demand for public services, while others are stagnating. Pockets of poverty, and underutilized human and natural resources still persist in many areas of the Commonwealth.

4. Local governments will face increasing difficulties in financing and delivering adequate public services to their citizens. Even though public infrastructures are deteriorating, less future support can be expected from the Federal government.

5. Public investment is a vital prerequisite for a balanced private investment program.

6. The needs of the Commonwealth will be effectively addressed only if state policy is sufficiently flexible enough to address this range of conditions in a positive, responsive manner.

7. The private sector is capable of providing a broader range of services including some which have 
traditionally been supplied by governments.

8. A limitation of many state and federal programs designed to assist rural areas is their limited scope and vision. Many programs deal with only one aspect of a very complex problem, have shortterm objectives, and result in a piece-meal approach to social and economic development. On the other hand, no single policy or program can simultaneously solve all problems associated with rural development.

Based on these issues, several working hypothesis were advanced.

1. A rural development institution must have a purpose and direction that does not duplicate the efforts of any other state agency. Instead, it should be designed to integrate the various subcomponents of existing programs, coordinating their efforts in order to have maximum impact on some of the most critical problems in rural and small-town Virginia.

2. An economic development program for the Commonwealth should be based on a constancy of purpose with a sufficiently long-term perspective to address the hard-core problems that have evolved over the past 50 years. A new public/private partnership must be forged building on existing state agencies, multi-county planning districts and local units of government.

3. Any new approach should draw on strengths of existing agencies, avoiding duplication of program efforts.

4. Multi-county planning districts should promote innovative programs at the local level. Public facility planning must be strengthened in order to provide access to a minimum level of public services to all citizens and to develop an infrastructure that will consolidate advancements in economic development and stimulate new ventures.

5. Program specific funding and technical assistance will be needed to address rural problems associated with water/wastewater, health, housing, education, transportation, energy, farming, and economic development. Yet, no program should be implemented that is not cognizant of the interrelationships among each of these subcomponents of an effective rural development strategy.

\section{Objectives and Structure}

The deliberations of the Rural Development Authority Task Force culminated in a recommendation for the establishment of the Rural Virginia Development Foundation including its specific objectives and overall structure. The objectives identified included the following:

1. To develop and promote programs of balanced economic growth in rural Virginia that are compatible with its cultural and economic environment. This initiative will require a venture capital fund to support entrepreneurial efforts to create value-added production in rural Virginia.

2. To develop a human capital program that insures the delivery of targeted and coordinated leadership and manpower training programs. These programs should be designed to meet the emerging needs of the rural public and private sectors, especially those enterprises developed by programs initiated under the first objective.

3. To create a resources coordinating committee to identify emerging needs in rural Virginia and develop highly qualified "think tanks" to address those needs. This objective will supplement the first two objectives by identifying emerging technological changes that generate products amenable to production by rural enterprises.

The Task Force felt that the comprehensive nature of this proposal merited further consideration by a broad cross-section of the public and evaluation by private and public agencies across Virginia. The base of support for the proposal should be appraised and alternatives evaluated through further research. In particular, it was suggested that two types of research be undertaken. First, a survey of private and public leaders at the local level was suggested as a means of determining the specific needs and wishes of rural areas. Second, it seemed essential to determine the approaches being undertaken in other states and their experiences with similar programs. Therefore, the Task Force recommended that the legislature be asked to create a joint legislative study commission to further evaluate this proposal and to insure public and additional professional input into its ultimate structure.

A Joint Subcommittee of the House and Senate was established to serve as a Study Committee by the General Assembly in the Spring of 1983. Virginia Tech research and extension faculty in the Department of Agricultural Economics and the Virginia Department of Agriculture and Consumer Services provided 
staff support for the Joint Subcommittee. This subcommittee met throughout 1983 and early 1984 to receive reports from its staff, presentations from concerned groups and individuals and to develop a legislative package to establish a Rural Virginia Development Foundation.

The subcommittee staff launched a survey of state activities across the U.S. in the area of finance development programs. Few programs were discovered which bore a close resemblance to the Virginia design. On the other hand, a great deal of interest was expressed in the type of plan envisioned for Virginia. The approaches being taken in other states proved useful during the development of Virginia's program. The subcommittee also surveyed over 400 local leaders in both the public and private sectors.

Among the significant findings of this survey were the following:

1. 97 percent of respondents felt there was a need for more industry in their area;

2. 63 percent said that business or industry starts had been either lost or delayed in the community over the past five years; the most common reason was inadequate capital financing;

3. 89 percent favored the concept of the Rural Virginia Development Foundation;

4. 83 percent favored the concept of rural venture capital corporations; and

5. Local government officials indicated a desire to participate financially in such corporations.

Based on this research and the input of a number of individuals and groups, legislation which would allow for the establishment of a Rural Virginia Development Foundation was drafted and revised. The joint subcommittee recommended the adoption of the legislation in its final report. (Joint Subcommittee).

A Bill (Senate Bill 279) to establish the Foundation was passed by both Houses of the Legislature in 1984 and was signed by the Governor on April 10, 1984. The Bill calls for a 17 member board to be appointed by the Governor and to consist of a cross-section of interest and experience. Members will be chosen on the basis of their proven ability and experience in dealing with economic development, business and financial management, and issues of public policy.

The board of directors will arrange themselves into three major standing committees which will constitute the basic structure and provide leadership for the RVDF's three principal objectives. These objectives are:

1. to promote and facilitate small industry and business development compatible with the unique resources and needs of rural Virginia communities;

2. to promote investment in the human capital of rural Virginia residents; and

3. to identify and encourage new approaches to capacity building in both the public and private sectors of rural Virginia.

Three committees will be organized by the RVDF Board to carry out these objectives. The role of each committee is discussed below.

\section{Role of the Enterprise Development Committee}

Objective one will be the responsibility of the Enterprise Development Committee (EDC) of the Foundation. The overall role of the EDC will be to identify and encourage the expansion of value-added production activities in rural Virginia, primarily through the provision of venture capital and other types of financial and technical support for small businesses. This role will involve the development of business enterprises based on new products, new markets, and new uses for existing products. Determination will also be made of the feasibility of replacing outside sources of inputs and consumer goods with local sources.

The emphasis of the EDC will be on expanding "value added" activities based on the agricultural and natural resource base of local economies. Additional processing and direct marketing are key examples. The approach is to build on local potential capabilities of entrepreneurship, management, and resources. Using the resources of a new venture capital corporation, the risk of these new ventures can be pooled. By complementing the capital with technical and mangement assistance, overall risk will be reduced.

This Enterprise Development Committee (EDC) will coordinate its efforts with the State's Department of Industrial Development (DID), particularly to identify new product requirements of recently located or expanding firms in Virginia. The potential development of needed inputs or the use of manufactured products as inputs into new product lines envisioned by the EDC could be an attractive aspect of locating in Virginia. In this coordinating role, the EDC may serve to stimulate industrial and business development in the state through strengthening backward and forward linkages with other businesses and 
industries. Duplication of efforts with other state agencies would be avoided by effective coordination.

The EDC will further help identify emerging technological trends that can enhance the income position of rural Virginians by coordinating its activities with the private sector, with planning district commissions, with the colleges and universities of the state, and with the Virginia Cooperative Extension Service. Efforts will be directed specifically to those businesses that appear likely to promote balanced economic growth and a healthy interaction between farm and non-farm business sectors. Food processing businesses and wood products industries, including house building, are examples of ventures which the EDC will consider.

\section{Role and Structure of the Virginia Economic Development Corporations}

A major task of the EDC is to provide direction for one or more proposed venture capital corporations to be called Virginia Economic Development Corporations (VEDCORP). These corporations will be forprofit, venture capital subsidiaries of the RVDF. Each will have an initial board of directors with some members in common with the RVDF board. As it becomes capitalized, a VEDCORP board will be elected by its stockholders following general corporate guidelines.

A major leadership role will be required for a VEDCORP to attract sufficient operating capital. The major support will come from local investors, private industries, and local governments and development authorities. The VEDCORP will offer counties an alternative means of supporting and encouraging local development. In addition state and federal agencies will be encouraged to provide funds through grants or loans to the VEDCORP. Principal sources may include the Farmers Home Administration, the Department of Housing and Urban Development, and the Small Business Administration.

Virginia Economic Development Corporations will provide loans, engage in equity financing and guarantee loans to firms in rural areas of the state. Special emphasis will be placed on providing support to new entrepreneurs and small business ventures.

The VEDCORPs will fill the following specific needs which generally are not adequately met by existing public and private agencies:

- The risk associated with each new venture will be pooled over all investments and a portion of the risk will be spread over public and private sectors.

- The cost of financial information and transactions will be minimized.

- Small, high risk enterprises which are frequently excluded from traditional credit sources will be favored.

- Additional sources of capital will be provided in communities with limited financial alternatives. Existing financial institutions will be encouraged to participate more fully in local projects.

- Assistance will not be restricted to any particular corporate form of organization, e.g., cooperatives, limited partnerships, community development corporations.

- Entrepreneurs in low income areas and in minority communities which have traditionally not received equal consideration will be given special attention.

\section{Role of the Human Capital Development Committee}

The second objective of RVDF will be the responsibility of the Human Capital Development Committee (HCDC). The efforts of this committee will be to identify and train new entrepreneurs and to upgrade the qualilty of labor and management skills needed to serve the future economic needs of the public and private sectors of the Commonwealth. The activities of the HCDC will be coordinated, through the board of directors, with the activities of the EDC and VEDCORPs. Training programs and similar human capital projects will be designed to provide the skills and capabilities needed by new and expanding enterprises.

Local government capabilities will be increased by leadership, management, and skills training to improve efficiency and productivity of local governments with emphasis placed on enhancing their ability to promote broad-based economic development. Coordination with existing state and federal agencies will be emphasized, and the resources of Virginia's four year colleges and universities and community colleges will be utilized.

The role of the HCDC will be to improve quality of life directly by increasing investment in human capital and indirectly by increasing the productivity of the labor and managerial forces. The committee 
will identify and coordinate relevant aspects of existing human capital programs as well as initiate new programs designed to promote the objectives of the RVDF, particularly efforts to promote entreprenuerial identification and training.

This committee will coordinate managerial and manpower training programs that improve efficiency and productivity in the private sector and promote capacity building development of local governments. Systematic efforts will be undertaken to upgrade the quality of human capital by targeting training programs toward the emerging needs of local governments, business, and industry. A program of entreprenuerial identification will be undertaken in conjuction with schools of agriculture, human resource development, business administration, engineering, public administration and planning.

\section{Role of the Resources Coordinating Committee}

The Resources Coordinating Committee (RCC) will be responsible for the third objective. The RCC will be aided by $a d$ hoc task forces designed to identify problems, develop alternative approaches to their solution, and generally serve in a "think-tank" capacity to deal with the emerging needs of rural communities. Members of the "think-tanks" will be individuals who are, through experience, academic training, or self-study, committed to examining creative, new approaches to economic change, community development and improved quality of life. The RCC will direct the "think-tanks" in such a manner that they support related efforts of the RVDF.

The RCC will draw on volunteer groups and private agencies to gain insight into new approaches to problem-solving that are based on grass-roots involvement. Extension programs, community colleges and other educational institutions may provide useful and practical applications of knowledge. Emerging technology for new rural business and industry can be identified and production schemes established. This economic-educational linkage will serve to enhance the economic and social interests of rural areas.

The RCC will function as a collector, disseminator, and medium for information and ideas. The committee will collect, evaluate, project and disseminate information through its task forces. These task forces, in turn, will attempt to systematically obtain information on pilot projects and experimental efforts that have proved successful in rural Virginia. As the RVDF's extension arm, the RCC will disseminate information relating to enterprise and human development. And finally, it will serve as a medium for transmitting ideas and information which should be shared with various agencies of federal, state and local governments. The intent is to invigorate public knowledge with innovative ideas and knowledge gained from experimental efforts. The work of various planning district staffs should be drawn on in this regard.

The RCC will identify select groups of scholars, citizens and business people whose purpose is to develop innovative approaches to social and economic problems of the state. These groups will meet on a regular basis at which time new approaches can be outlined and discussed. This committee will hold meetings at various locations across the state to encourage broad participation and to elicit ideas.

\section{The University's Role}

The development of the Rural Virginia Development Foundation by faculty at Virginia Tech and colleagues in the Virginia Department of Agriculture and Consumer Affairs represents a case study of the research-extension integration advocated by proponents of Title $\mathrm{V}$ of the Rural Development Act of 1972. The final bill signed by Governor Charles Robb on April 10, 1984 reflects the culmination of careful problem identification, an assessment of both theoretical and applied research on rural enterprise development, and the political process. Each of these components will be briefly discussed.

\section{Problem Indentification}

The need for a creative, public-private sector partnership to promote balanced economic growth and provide access to a range of public services grew out of reports and studies, including:

1. legislatively mandated study commissions cited above,

2. the NSF supported study by Farmer et al., Capacity Building Needs of Rural Areas in Virginia,

3. a series of needs assessments made in counties targeted by the Title V Rural Development Project of Virginia Tech, and

4. a special survey conducted during the deliberations of the Joint Subcommittee. 
Recent research was cited for the Committee which underscored the importance of small businesses in the economic development process. For example, four-fifths of all the new jobs in America between 1974-80 were created by establishments with less than 100 employees. In Virginia, 23 percent of employees are employed by establishments with less than 20 employees and 46 percent by those with less than 100 employees. Furthermore, over a span of 20 years, small businesses have developed 24 times as many innovations per research dollar as have large firms (Shaffer). This impressive record has been achieved despite the limitations arising from limited venture capital and technical assistance available to small firms.

Findings such as these which emphasize the importance of small businesses drew on the work of David Birch, Shaffer and Pulver, and others (Community Economics). This issue struck a responsive chord among legislators in Virginia, many of whom are closely associated with the struggles of small businesses.

Also, the early work of the Task Force was influenced by the need to expand the base of capital ownership through equity financing. The attention given by researchers to community development corporations and small business investment schemes were important ingredients (Abt. Associates Inc.; Deaton; Sabre Foundation). This body of research provided examples of relative success under varying structures and institutional arrangements.

During the Subcommittee deliberations questions were raised about the constitutionality of allowing County governments to make equity investments in a venture capital corporation. The Attorney General's office expressed doubts about this provision. In response, we proposed a modification that would enable counties, towns, and cities to purchase guaranteed "development services" from the RVDF. In turn, the Foundation could use these funds to capitalize the venture capital corporation.

\section{Economic Concepts and Political Reality}

University faculty must remain strongly committed to professional integrity and scientific objectiveness when dealing with topics that hold political implications. However, this is not to suggest that faculty members should take a "heads-in-the-sand" posture toward political maneuvers, bureaucratic manipulation, and seemingly inexplicable behavior brought about by hidden agendas. Policies, programs, and new institutions do not develop in the idealized environment of economic theory, but, rather, in the real world with its complicated environment of individuals, lobbyists, and political and constitutional institutions.

Essentially, we feel that University faculty must become more aware of the complexity of political decision making, respect the importance of traditions and values in public decision making, and realize the gravity of issues reflected in turf battles among different departments of state government and among personalities within a given department. Legitimacy in professional matters is developed through both personal and professional integrity. Expertise is vital, but it must be applied within a framework that is often amorphous and subject to unexpected changes. Being able to anticipate likely consequences of proposed action under hypothetical future scenarios is a valuable, needed asset.

The process which led to the Rural Virginia Development Foundation illustrates these points. Following are just some of our experiences:

1. Politicians are sensitized to certain language, phrases and even words. In addition to their well known distaste for "economese" and other professional jargon, politicians shy away from words which have special connotations to them. We quickly discovered that such words as risk (risk capital), venture and equity (equity investment) had suspicious connotations.

2. Politicians, lobbyists, and bureaucrats are generally receptive to good ideas but are suspicious of anything they don't fully understand. At the same time, they are generally too busy to seek out the necessary explanations. Instead, it is the academic's responsibility to initiate the education process and to ensure that the policy makers understand all aspects of the proposal.

3. One can probably not gain the support of all interest groups. In our case, we were opposed by a leading farm group because the proposed Foundation "went too far" and another group because it "didn't go far enough." In this case at least, lack of support did not necessarily turn out to be a disadvantage.

4. Bureaucrats are necessarily territorial, and will predictably be skeptical of programs initiated outside their purview. It is difficult to argue that a need exists without being interpreted as saying 
that someone is failing. The academic must learn to anticipate these "turf battles" and to involve the potential antagonists in the deliberations at an early stage.

5. Related to the last issue is that of the implications of new proposals for existing programs. There is a natural tendency for proponents of a new program to argue that it plugs holes in existing programs. It is much more effective (and no less professional) to point out the complementaries between old and new programs. The conservative nature of the political process gives a decided edge to the status quo when a proposal "makes waves."

6. The timing is of utmost importance in the political process. Some programs are most attractive to candidates before an election while others are much less so. Some programs tend to be identified with currently popular issues. Intepreting these matters is generally foreign to our academic training and our general approach to policy analysis.

7. The academic must decide which features of a proposal are essential and non-negotiable, and which can be changed without seriously compromising the integrity of the program. We were faced with the possibility that financial involvement by counties was unconstitutional. Since we believed that such involvement was essential we sought an alternative mechanism to permit their involvement rather than delete this option. On the other hand, we felt that state financial support was desirable, but it became apparent that such support was not politically feasible at the time. We therefore opted for the legislation without state financial support.

\section{Conclusions}

University personnel will most likely find themselves increasingly caught up in state-level policy formation, implementation, and evaluation. The decentralization of federal government authority and/ or finance makes this a challenging prospect. Research-extension integration must become the trademark of an effective university role.

Equally important is the understanding that policy formation is a joint product of intellectual input and political process. The same intellectual inputs will yield various outcomes as they are shaped by alternative political processes.

The Rural Virginia Development Foundation is one product among a wide range of state economic development programs that are currently emerging across the nation. The principal elements of the Foundation represent a cohesive program to address the priority needs of rural areas of Virginia. The remaining challenge is to successfully maintain the intellectual framework of the RVDF concept while effectively implementing the program.

\section{FOOTNOTES}

${ }^{1}$ Symposium on Local Leadership and Rural Development, sponsored by the Organization for Economic cooperation and Development (OECD), Washington, D.C. and Williamsburg, VA, April 16-20, 1984.

In 1983, 64 percent of total farm household income in the U.S. was received from off-farm sources.

\section{REFERENCES}

Abt. Associates, Inc., An Evaluation of the Special Impact Program: Phase I Report, Vol. I, 1972.

Brady J. Deaton, "CDCs: A Development Alternative for Rural America," Growth and Change, Vol. 6, No. 1.

Community Economics, Various issues, Department of Agricultural Economics, University of Wisconsin.

Farmer, Berkwood M.; Anthony A. Hickey; Edward H. Hansen, Irl W. Smith and Mark A. Silverman. Capacity Building Needs of Rural Areas in Virginia. Virginia Department of Agriculture and Consumer Services, Richmond, Virginia, September, 1978.

Jequier, Nicolas, "Appropriate Technology for Rural Governments," Theme Paper No. 3, Cooperative Action Programme, Local Leadership and Rural Development, Organization for Economic Cooperation and Development (OECD), Washington, D.C. and Williamsburg, Virginia, April 16-20, 1984.

Pulver, Glen C. "Venture Capital." Community Economics, No. 88, Department of Agricultural Economics, University of Wisconsin, January, 1984. 
Report of the Joint Subcommittee studying the Development of a Rural Virginia Development Foundation, Senate Document No. 12. Commonwealth of Virginia, Richmond, 1984.

Sabre Foundation, Expanded Ownership, (Staff Report), Sabre Foundation, 1972.

Shaffer, Ron. "Economic Development Trends." Community Economics, No. 69, Department of Agricultural Economics, University of Wisconsin, June, 1982. 